University for Business and Technology in Kosovo

UBT Knowledge Center

Nov 2nd, 5:15 PM - 5:30 PM

\title{
Enforcement Of Legislation For Labor In Kosovo And It's Reformation
}

Blerim Krasniqi

Follow this and additional works at: https://knowledgecenter.ubt-uni.net/conference

Part of the Law Commons

\section{Recommended Citation}

Krasniqi, Blerim, "Enforcement Of Legislation For Labor In Kosovo And It's Reformation" (2013). UBT International Conference. 50.

https://knowledgecenter.ubt-uni.net/conference/2013/all-events/50

This Event is brought to you for free and open access by the Publication and Journals at UBT Knowledge Center. It has been accepted for inclusion in UBT International Conference by an authorized administrator of UBT Knowledge Center. For more information, please contact knowledge.center@ubt-uni.net. 


\title{
Enforcement Of Legislation For Labor In Kosovo And It's Reformation
}

\author{
Blerim Krasniqi
}

\begin{abstract}
Legislation for labor relation in Kosovo administered by UNMIK but even after the country's independence, especially its implementation and efforts to reform them are subjects and issues which preoccupies the society and the employees in Kosovo. Establishment, enforcement and reformation of Labor Legislation in Kosovo after 1999 can be clearly divided into two periods such as: The period of UNMIK Administration until the entry into force of the labor legis lation in the Republic of Kosovo and the second period the strengthening of labor legislations after the country's independence. The process of reformation of labor legis lation has indicated few tendencies for reformation which have not been reached the adequate level of development. In opinion, is described the fact that labor legislation in Kosovo is facing to many difficulties, which occasionally are reported and elaborated in different reports and researches. The reports made on this issue seclude particularly the legislation being not full in the labor field and certain mechanisms which will ensure the adequate enforcement of legislation and legal protection for employees.

The issue which is elaborated in this project is the fact that enforcement of legislation and certain implementing mechanisms as well as its further reformation, is it a problem which continues to challenge its adequate enforcement? Regarding to this, by analyzing the positive legislation and pertinent literature, the item aims to treat the aspect of implementation in practice of labor legislation, respectively how much and how mechanisms for implementation performs, and what is the dedication of government and society overall to move forward on this direction.
\end{abstract}

Keywor ds: Labor legislation, enforcing mechanisms, reformation, creation, reports.

\section{Introduction}

The engagement of country legis lation on development of a genuine legislation and efforts made for its enforcement through respective mechanism had been associated and are being associated with many different challenges which are of different natures. Legal base, respective actions undertaken in the execution of labour regulation in Kosovo in general and tendencies for its reformation note the content and the focus of this topic. The process of implementation and reformation of labour legislation during this period has marked many reformation and development tendencies, but never achieved the level of implementation nor adequate development.The abovementioned highlighted area as well as the aspect of labour regulation execution will be elaborated in the continuance of this paper.

The uniqueness of it is that applicable labour regulation in different institutions has marked tendencies of separate development. At first, different institutions had their internal normative base, and their actions were based in internal rules entered into force by UNMIK administrators depending where they came from, and later by local leaders of those budgetary organisations or institutions. The implementation and reformation of labour legislation and its reformation is in the centre of attention of respective institutions and mechanism since the society and institutions are waiting for executive mechanism functionalising and their best possible performance.

Assuming to analyse labour regulation and its implementation in political and economic processes that the country is facing, I have highlighted the legal base, difficulties and some of the violations encountered during this period. Findings of this article evidence the fact that the time period from 1999 until now is been worked fairly on compiling and implementing of labour legislation in general whose legislation has encountered and continue to encounter difficulties during its practical execution. Implementation difficulties and delays are mainly met on labour law enforcement, while law enforcement of civil service as we shall see is presented in a slightly higher level of implementation. 
Relatedness between human work and dignity emphasized and incorporated in ILO's Constitution in 1946, where is emphasized that "Work is not product and that all human begins have the right to follow material wellbeing and their spiritual development in conditions of freedom and dignity,of economic security and equal opportunities"will be the judgment that will permeate this paperwork.

After the leaving of Serbian Government and Administration from Kosovo, UNMIK Administration in Kosovo beside the applicable legislation has taken legal obligations on implementation of international convents from labour relations. This commitment is foreseen at UNMIK regulation UNMIK, No. 1999/24 "For the law in force in Kosovo, which inter alia states the fact that during the exercise of its functions, all people with public duties or that hold public positions shall respect known international standards of human rights as foreseen in international declarations and convents.

Even if formally said that in Kosovo are applied provisions before 1989, this time when Koso vo had its own laws that regulated employment relations, in practice there are few cases when those provisions are applied. This aspect of non-implementation in practice of respective provisions related to this is sue has committed violence of Workpeople Rights in Kosovo during the time of UNMIK administration. Regulation No.2001/09 "Over the Constitutional Framework for Provisional Self-Government in Kosovo" in premise, among others called and in different convents where is been said that the obeis ance of different convents and standards against the discrimination is presented and is permanent duty ofall authorities, organisations and temporary self-government structures.

In after war period in Kosovo mainly in three first years cannot be mentioned any gen uine execution of labour law in any budgetary organisation or private/social company, because we didn't have the consolidation of the ascendancy and mechanis mthat would care about the adequate execution of labour rights. Regulation No. 2001/27'Over the Basic Law of Labour in Kosovo" and Regulation No. 2001/36 "Over Law for Civil Service in Kosovo" were the key legislation for regulation of employment relations in Kosovo.The specific of the legal base for civil servant is the fact that we already do not have work contract for unspecified time, but we have contractual relationship in the period commencing from one to three years.

SRSG through the regulation determined basis and frames on regulation of employment relation in Kosovo, creating mechanism that would care in order to implement respective rules and procedures but also to develop necessary and imperatival legislation and normative.

Basic criteria on implementation of regulation are foreseen on article 2.1 of Rule No. 2001/36, stating: "Civil service will be leaded by those elaborated principals as below: (a) Equally; (b) Political neutrality and objectivity: (c) Sincerity; (d) Honesty and responsibility; (e) Transparency; (f) Merit; (g) Nondiscrimination (h) Comprehension", etc.

Findings of this paper evident the fact that in the time period of 1999 until now is been worked enough in compiling and strengthening labour legislation in general which legislation have met difficulties during its practical implementation.

The enforcement of labour law in Kosovo due to different experts of this field, reports and opinions, although by interviews and different conversations with columnist and executors of this act, since its enforcement there are evidenced some problems related to its non - implementation. According to different reports and interviews, different employers, are not implementing it also some private businesses are doing the same, and continue to operate without any problem. Labour Inspectorate seems to be impotent to sensitize the owners not to violate labour's law and rights through blackmail and firing intimidation. In this situation seems that the firing intimidation is the only depreciator that forces employees to remain silent. Another problem continues to be the maternity leave issue and other leaves in general that are challenging and quite undistinguishable mainly in private sector.

There are also evident violations by employers of different sectors such as building, agricultural, medical, hotel etc., requesting from employees to work longer than determined timetable, without safeguard measures and without work contract. It is also clear the fact that in our actuality, in our society, the most difficult mission for each citizen is finding a job. On the other side those who are employed face difficulties because of non genuine compliance of labour law and due to some defects that this law has had during its compiling.

In the other side, if we link the problem with a need of possessing an organic labour law, but without analysing the aspect of practicability, than such Labour Law has its positive sides, because in the event of setting a good legal base for employees and those to be feel more assured in their place of work, to 
have guaranteed rights, does not allow at least formally that the employer to violate the right of the employee and at once provide salary and vacation compensation for all employees.

If we compare the current labour law with regulation for labour basic law 2001/27 that was juridical base for improving labour relation to the issuing of a new law, we may notice that there are some tiny differences between these two acts. Labour law unlike regulation for basic labour law 2001/27 is more favourable and mainly for people under 18 , because in case they get employed cann ot work within a week 40 hours as people more than 18, but, will work 30 hours within a week, which are considered full working hours. If we refer to the general principals of the labour rights, different convents and also human reasons, that is it right and moral that the employer to deprive the employee from his legitimate right? According to many data and conversations with anonymous employer and employees in many businesses there are employed relatives, on which event are at least performed two violence, as a employee in the juridical formal aspect but also in human and moral aspect, too. It is a fact that earnings in private sector in general are very low so in this aspect we shall understand the approach and opportunities of the employer, since employees and employers share the same fate of the economy of the country, economic trends and another more global aspect, but, it cannot be justified and understood that why the employer does not have work contract, why he is obliged to work more than forty hours in a week without due compensation, etc?

Field analysts based on field work explain that one of the reasons why one government shall interfere in the labour market issuing laws in order to regulate it, is that labour markets are nor perfect and consequently employee through the power of the market they posses, mis use the employees by bringing unfairness and non-efficiency. Law enforcement requires the engagement of the employee, employers and labour inspectorate. Employer shall be informed with provisions that Labour Law foresees, with obligations that has to employee and with punitive provisions that is foreseen by law in case of violation of his right. Concisenessshall happen as soon as possible and employee shall know that is case if employer denies those rights, the law guarantee protection after the complaint is submitted within institution, than in court or in labour inspectorate. Labour inspectorate shall be more often present in the field, in order to listen the complaints of employees and to be without compromise toward themwho violate Labour Law and the rights of the employees. It remains legal obligation of labour inspectorate to monitor Labour Law enforcement, as far as the employer is aware on how to respect the rights of employees which are a legal but also moral obligation.

Beside non-compliance of the law by employee, one another problem also exists, inefficiency of municipal courts to resolve contests from labour relations and as a result of this often come to the hesitation of the employees to address the courts in order to require justice in case if their work contract is discontinued in arbitrary manner by employer. By the content of labour law and of civil servant has differences and mainly with the time table within a working day and brakes within one day that belong to the employees. Labour Law determines 30 minutes brake within 8 working hours and this provision is respected by private sector. In another hand law for civil service who gives a chance to the civil servants to have (1) one hours brake within eight (8) working hours and this in employees convenient, but not to the state, so thus it seems that laws are not in harmony and employees in this aspect are not equally treated as in private sector also in public one. Even if the majority of employees are aware that in Kosovo exists a Labour Law, nevertheless only few of them know the content of the law and what rights are guaranteed by this law. This ascertainment came during the publication of Report over Labour Law enforcement in Kosovo. Due to the report in question, "the most worried findings are that during the monitoring we have found over 56 percent of the employees work without working contracts. So, they have only one kind of agreement with employer that is a violation of their rights. As unionists expressed, quote" We require the implementation of laws in practice for the rights of employees, we require the endorsement of collective agreement in national level which is prepared, we require the implementation of minimal wage agreement that social economic council has taken this year, in order that to be 220 euro" said in publication.

During a debate for Labour Law, respectively maternity leave, organized by Centre of Human Rights in University of Pristine, there are discussed amends of the labour law, amends that, according to majority of panellists, are drawback for females. In the same debate many legal officers have given their opinions regarding the harmonisation of national legislation with EU legislation in the Ministry of Labour and Social Welfare, who said that even after harmonisation, the proposal related to woman after child-birth is applied a leave of 9 month with a payment, it has been inadmissible for World Bank. 
Ombudsman, Sami Kurteshi, has said that this law has more negative than positive amends. Kurteshi has evaluated that the law in current form is inadmissible no matter what kind of amends will be done, according to him, monitoring mechanism shall be raised on the implementation of Labour Law in general. Whereas the proposal of the Chamber of Commerce for the payment of maternity leave, that the payment for woman after the child-birth to be 4.5 months from businesses and 4.5 months from The Government of Kosovo, evaluating as an acceptable proposal by businesses. Law enforcement of civil servants in Kosovo is a precondition of the functioning of a functional public administration. Civil Service, respectively administration implementing bodies are key provider of public services. Regarding the implementation of law, in field there are performed researches and analyses regarding the issue of secondary legislation of Law enforcement. Information over the development of Law enforcement bodies for civil service are collected by different institutions, through interviews with officers of administration and personnel departments in 34 municipalities and 12 ministries. All respected evaluated ministries and the majority of evaluated municipalities have developed implementing bodies, as determined by Law for Civil Service. Nevertheless, secondary legislation on Implementation of Law for Civil Service is not finalized yet.

The process of transformation of civil officer's contracts to the act of nomination with the indefinite term has been completed only in 67percent of assessed ministries and in 62 percent of municipalities, against the certain term for termination of this process in July 2011. As a part of wider reform of public administration, reforms in civil service are defined in Law for Civil Service that entered into force in 2010. Legal package for 2013 that will include the reformation of public administration due to local executive, perform obligations that come from pointed remarks by the Feasibility Study for Kosovo. With legal package, government alleged that has included in legal programme of this year all laws that have to do with the reformation of public administration due to required criteria by European Union. Innovation in this legislative package is the law that defines the wages of civil se rvants and political staff, "Law for civil service and wages, such laws that need to be changed. As already stated, Law for civil service requires many sublegal acts to be approved within six months or a year since the date of entry into force, according to the issue that they treat. Until December 2012, MPA and Government have issued in total 21 sublegal acts. A disorderly is sue was the non-proportionalunder-representation of roman, Egyptian community in Kosovo in all levels of civil service. Regarding gender representation, provided statistics by MPA shows that as institutions in central level also those in local level were almost in full accordance with their legal obligations in order to provide the representation of females of at least 40 percent of civil service employees, by 36 percent in central level institutions and 41 percent municipal institutions. The lack of a regulation for categorizing of vacancies would clarify the process which is approved in March 2012, has procrastinated the process of contract's transformation in many municipalities.. Highlighted elaborations and examples in this article reflect the implementation of labour legislation in Kosovo that demonstrate the need for determined amends and progressions in the labour area in Kosovo. Unlike the 2012 Feasibility Study, among others it is said that delays in the implementation of the new legislation undermine the creation of a public professional administration and create conditions for a legal vacuum that is detrimental for the reform process. In a very short time, Kosovo shall approve all sublegal acts for laws over civil service as well as wages for civil services and care for the implementation and respect for the law and respective procedures in order to evident the commitment for their implementation.

\section{Conclusions}

Analysing applicable regulation of labour in Kosovo in general and analysing reports of many mechanism that have performed researches for the level of practicability of labour regulation and attempts on its reform in Kosovo despite the social and political achievements after 1999, labour applicable regulation, respective mechanism and the level or practicability, evaluated as nonappropriate level. The rights of the employees in Kosovo are not pleasingly respected, yet. Unionists are not satis fied with the implementation of law in employment areas. Employees have addressed many complaints, mainly related to the working contracts and other violations performed in economic private sector. While many issues are already regulated with secondary legislation, there is a need of other regulations in order that the Law for Civil Service to be fully executed. The transformation of civil service contracts into the act of nomination with indefinite term is a process that is not finished in the 
majority of institutions yet. The independent body responsible for the adjudication of the civil servants according to the Law for civil service is facing with considerable challenges. Some issues by labour area were absent and left to the time (such as: different health and social insurance, health, material compensation of curing expenses, for the injured or disabled officer or close family of the decedent officer, etc. Different reports emphasize as summarized the conclusions such as: weak professionalism, politicization, lack of qualification, lack of legislation and implementing mechanism, etc. Labour reformation and regulation development stagnated, respectively are very slow and depended among others on budgetary potential. The duration of vacations, maternity leaves, medical leaves etc. was shorter and in some aspects contray with foreseen rights on the international convent. It is noteworthy the zeal of institutions to achieve the level of ethnical and gender representation commensurate to legis lation in force and other higher standards.

\section{References}

1. Bujupi. Hava , 2007 , E drejta e punës, Prishtine

2. Dimitrov, Vesselin, Klaus H. Goetz, and Hellmut Wollmann. 2006. Governing after Communism:Institutions and Policymaking. Lanham, Md.: Rowman \& Littlefield.Resolution 1244 of Security Council of UNO.

3. Qela. Kudret,2003, "E Drejta e Punës" I dhe II, Tiranë

4. Regulation 1999/0,1 "Over Authorization of Temporary Administration in Kosovo".

5. Regulation 2001/9 "Constitutional Frame of Self-Governance in Kosovo".

6. Regulation 2001/27 "over Basic Labour Law in Kosovo".

7. Regulation 2001/36 "over Civil Service of Kosovo".

8. Administrative Order 2003/02: “over the Implementation of the Regulation No. 2001/36" over Civil Service of Kosovo".

9. MPS, "Personnel Management Digest", 2003, Pristine.

10. Law no. 03/L -149 for civil service of Kosovo, 09 July 2010

11. Law No.03/L -212 on Labour, 1 November 2010

12. Zeri:http://www.zeri.info/artikulli/3/21/29283/mos -zbatimi-i-ligjit-te-punes-nga-biznesetprivate/date: 14.10 .2013

13. http://www.kryeministri-ks .net/?page=2,177 (accessed on 6 June 2012).

14. http://www.osce.org/kosovo/99606.

15. Centre for Policies and Advocacy published the periodical Report over the Implementation of Labour Law in five municipalities in the region of Pristine, Bota Sot | 27.09.2012

16. Government of Kosovo, Kosovo Assembly Public Relations Strategy 2012

17. Government of Kosovo, Legis lative Program 2013

18. Government of Kosovo, Strategy on Local Self-Government 2012-2015

19. Organisations for Security and Collaboration in Europe, Mission in Kosovo, the implementation of civil service legislation in Kosovo, February, 2013

20. Action Plan of European Partnership 2012

21. UNDP and USAID, Public Pulse Report 4, August 2012.

22. USAID, "Human and Institutional Capacity Development Handbook", August 2011 and USAID, Human and Institutional Capacity Development Assessment: Kosovo, August 2012.

23. USAID, Human and Institutional Capacity Development Handbook, August 2011

24. USAID, Human and Institutional Capacity Development Assessment: Kosovo, August 2012 